\author{
Сніткіна I.A.
}

\title{
ПІДХОДИ ВИЗНАЧЕННЯ СУТНОСТІ ПЛАТОСПРОМОЖНОСТІ ТА КЛАСИФІКАЦІЯ ФАКТОРІВ ВПЛИВУ
}

\begin{abstract}
Для підприємств присутня постійна загроза невиконання своїх зобов'язань у будь - який проміжск часу, щзо в результаті відбивається на перспективах їх подальшого існування. Розглянуті основні підходи визначення терміну платоспроможності. Запропоновано групування визначення платоспроможності: як здатності виконувати свої зобов 'язання, як показника фінансової стійкості, як ліквідність підприємства, як здатність покривати збитки. Надане уточнене визначення платоспроможності як здатність суб'єкта господарювання своєчасно $і$ в повному обсязі розрахуватися за своїми поточними борговими зобов'язаннями за рахунок власних наявних ресурсів із збереженням безперебійного здійснення основних процесів функціонування підприємтвв. Запропоновано групування факторів впливу на платоспроможність того чи іншого суб' єкта. Основні класифікачійні ознаки групуються за признаками i характеризують зміну рівня платоспроможності за рахунок впливу відповідних факторів. Надана класифікація факторів платоспроможності дає можливість моделювати прочес ї̈ забезпечення, здійснювати комплексний пошук внутрішньогосподарських резервів з метою ї̈ збереження або підвищення.
\end{abstract}

Ключеві слова: платоспроможність; ліквідність; фактори; зобов'язання.

Постановка проблеми. Становлення ринкових відносин в Україні вимагає від вітчизняних підприємств підвищення відповідальності та самостійності у розробці та прийнятті управлінських рішень. Важливим фактором у цьому процесі виступає врахування інтересів великої кількості груп зацікавлених осіб: власників підприємства, його працівників і клієнтів, безпосередніх споживачів продукції, бізнес-партнерів, постачальників, органів влади, громадських організацій тощо.

Виконання підприємством своїх зобов'язань, а також відповідність очікуванням перелічених груп осіб залежить від того, наскільки воно здатне визначати ці очікування та потреби, ефективно їх задовольняти, підтримуючи оптимальний баланс між залученими ресурсами та створеним додатковим продуктом. Ця здатність підприємства потребує ефективної координації дій у фінансовій сфері та залучення найбільш передових технологій управління ресурсами. Вимога збалансованості фінансових ресурсів 3 точки зору їх джерел і напрямків використання породила одну 3 ключових проблем ринкової економіки - проблему забезпечення платоспроможності господарюючого суб'єкта.

Високий рівень платоспроможності необхідна складова стабільності функціонування будь-якого суб'єкта господарювання. На основі

(c) Сніткіна I.A., аспірант, Одеський національний економічний університет, м. Одеса, тел.0980483880, snitkinaia@gmail.com даних про платоспроможність керівництво підприємства вивчає ефективність його роботи та визначає шляхи подальшого розвитку, наявні та потенційні партнери обгрунтовують доцільність співпраці, інвестори оцінюють ризики вкладання коштів, а кредитори визначають можливість i загальні умови надання позики. Саме тому в умовах динамічного розвитку ринкової економіки $\epsilon$ потреба у формуванні визначення сутності платоспроможності та передумові банкрутства.

Аналіз останніх досліджень. Окремими методичними, організаційними та методологічними аспектами дослідження платоспроможності займалася i займається велика кількість іноземних i вітчизняних науковців. Зокрема варто виділити праці таких західних економістів як Й. Ворст, Л. Берстайн, Є. Брігхем, Дж. Ван Хорн, Дж. Депалленс, Дж. Джоборд, Дж. М. Кейнс, Л. Клейн, Р. Найт, Д. Нортон, П. Ревентлоу, М. Фрідман та інші. Значний внесок у дослідження проблеми був зроблений російськими науковцями - $\mathrm{M}$. Абрютіною, М. Болюх, А. Грачовим, В. Ковальовим, М. Крейніною, Е. Уткіним та А. Шереметом. Важливе теоретичне та практичне значення мають роботи й українських вчених: В. Мельник, Є. Мних, О. Наконечної, Г. Старостенко, Ю. Цал-Цалко. Проте, не зважаючи на велику кількість робіт і багаторічні дослідження теми, автори так i не дійшли до єдиної прийнятної думки щодо проблеми платоспроможності. 
Формулювання цілей статті. Метою статті $\epsilon$ дослідження підходів визначення сутності платоспроможності, факторів впливу на рівень платоспроможності та їх класифікація.

Опис основного матеріалу дослідження. На мікроекономічному рівні під платоспроможністю підприємств розуміють здатність юридичної особи або фізичної особи-підприємця здійснювати необхідні платежі. Ці платежі можуть здійснюватися 3 власних або залучених коштів для задоволення потреб усіх можливих контрагентів, включаючи обов'язки перед працівниками, а також потреби держави. Таке тлумачення терміну означає необхідність здійснення розрахунків як усередині підприємства, так i за його межами. Однак грунтовне наукове дослідження потребує більш глибокого, сутнісне вивчення даної категорії та з'ясування вихідних коренів її походження.

На сьогодні існуе багато визначень платоспроможності підприємства. Більшість вчених пов'язує це поняття із здатністю розплачуватись за існуючими зобов'язаннями. Так, М. Бердар під платоспроможністю розуміє здатність виконувати власні зобов'язання [1].

М. Крейніна вважає, що платоспроможність це наявність у підприємства фінансових можливостей для регулярного та своєчасного погашення боргових зобов'язань [2, с. 32].

В. Іващенко та M. Болюх трактують платоспроможність у якості показника фінансової стійкості підприємства [3]. Ототожнюють фінансову стійкість із платоспроможністю й інші вчені, як то I. Зятковський [4] та I. Макарчук [5]. На наш погляд така думка $є$ хибною $з$ тієї точки зору, що ці поняття характеризують різні позиції загального стану підприємства. Якщо платоспроможність - це зовнішній прояв фінансового стану господарюючого суб'єкта, то фінансова стійкість - його внутрішня сторона, що пов'язана із загальною фінансовою структурою підприємства і відображає збалансованість грошових і товарних потоків, доходів і витрат, коштів і джерел їх формування у довгостроковій перспективі.

А. Мазаракі, Л. Лігоненко та Н. Ушакова надають більш широке визначення платоспроможності, згідно 3 яким ця категорія визначається відповідністю витрат і доходів підприємства, яка забезпечує можливість постійного або періодичного фінансування функціонування та виконання взятих зобов'язань $[6,7]$.

Одне 3 найбільш точних, на наш погляд, визначень платоспроможності дає O. Непочатенко, згідно 3 яким - це можливість суб'єкта наявними грошовими ресурсами своєчасно погасити існуючі строкові зобов'язання $[8$, c. 365$]$.

Згідно 3 думкою більшості авторів, платоспроможність підприємства означає наявність у нього коштів або їх еквівалентів, які будуть достатніми для розрахунків за заборгованостями, що вимагають негайного погашення. 3 огляду на це, основними ознаками платоспроможності можуть виступати: наявність коштів на рахунках підприємства в достатньому для платежів обсягу; відсутність простроченої кредиторської заборгованості [9, с. 217].

$\mathrm{y}$ той же час ліквідність підприємства більшою мірою визначає його платоспроможність за умови наявності у складі поточних активів високоліквідних елементів [10]. Таким чином, господарюючий суб'єкт, дебіторська заборгованість якого належить неплатоспроможним клієнтам, а більшість запасів не відповідають ринковим вимогам, може характеризуватися високими значеннями ліквідності, але при цьому бути майже неплатоспроможним. 3 іншого боку, наявність у підприємства грошових коштів, які є достатніми для здійснення поточних платежів сьогодні, не дає жодної гарантії 3 приводу його платоспроможності у подальшій перспективі, тобто його ліквідності.

Уточнюючи різницю між двома категоріями відмітимо, що ліквідність підприємства характеризується рухом фінансових потоків, а платоспроможність визначається рухом грошових потоків. Обидва потоки знаходяться у взаємозалежності і рухаються паралельно один одному.

Слід також зазначити, що більшість економістів пов'язують категорію платоспроможності зі здатністю суб'єкта розраховуватися за своїми короткостроковими зобов'язаннями, але зустрічаються й протилежні точки зору, коли платоспроможність детермінують як здатність підприємства розраховуватися за довгостроковими зобов'язаннями, а здатність розраховуватися за короткостроковими називають ліквідністю [10, с. 34-35].

На основі проведеного аналізу виокремимо основні відмінності між феноменами ліквідності та платоспроможності:

$$
\text { платоспроможність підприємства }
$$
детермінується наявністю поточних активів у грошовій або іншій високоліквідній формі; ліквідність характеризується розміром та складом поточних активів суб'єкта; 
- стан платоспроможностіє більш динамічним, ніж стан ліквідності;

- за допомогою показників ліквідності можна охарактеризувати як поточний, так і майбутній стан підприємства; платоспроможність характеризує лише теперішнє положення;

- фінансові потоки визначають ліквідність, грошові - платоспроможність.
Власні визначення платоспроможності, які так чи інакше перекликаються 3 переліченими, надають й інші вчені - Й. Ворст, В. Мельник, Л. Лахтіонова, Н. Тарасенко, М. Чумаченко та інші. Систематизація їх думок з огляду на визначення означеної категорії наведена на рис. 1.

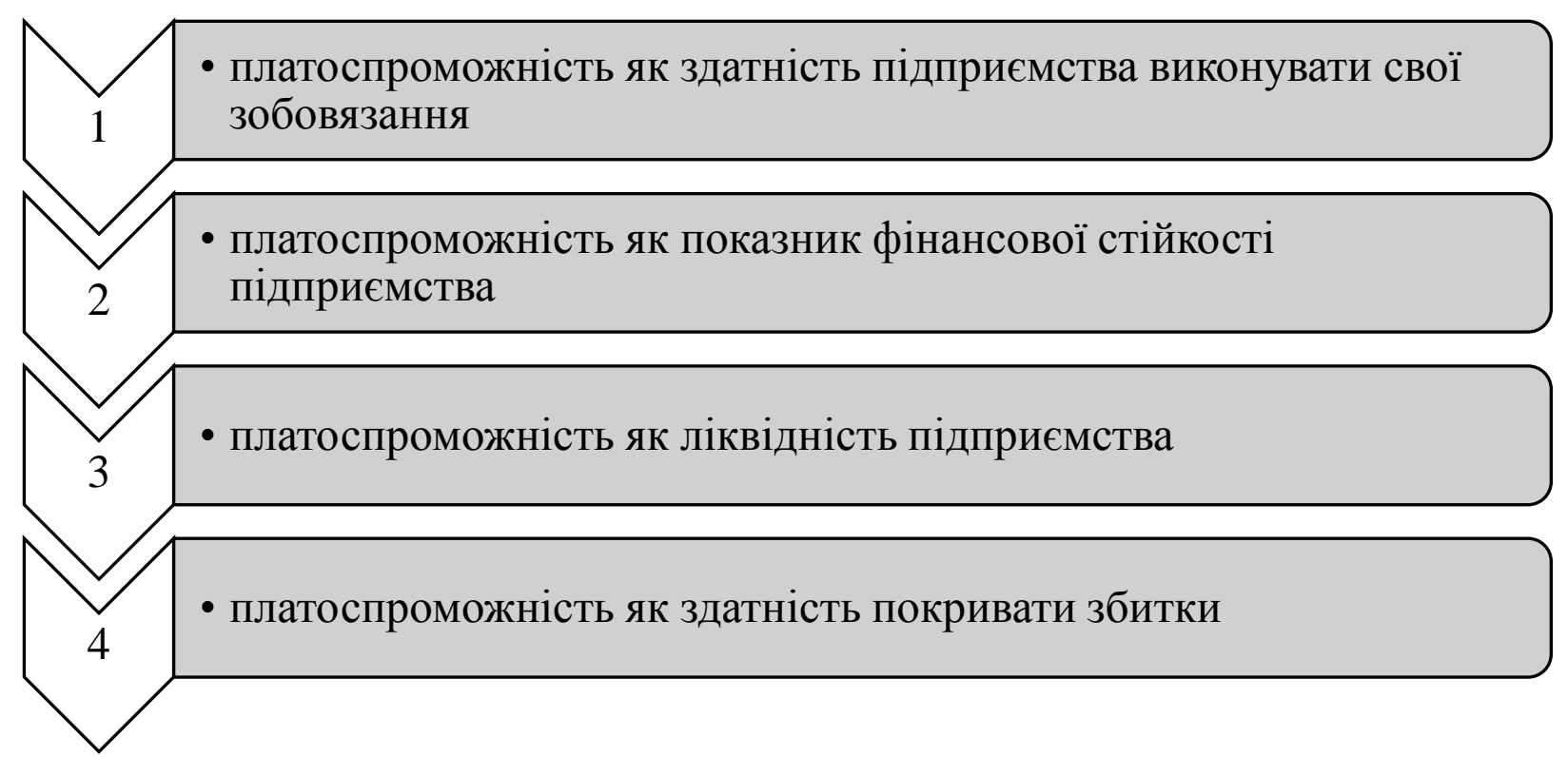

Рис. 1. Підходи до визначення економічної сутності платоспроможності. *

* Складено автором

Розглянувши поняття платоспроможності різних авторів, ми можемо зробити висновок, що всіх їх об'єднує позиція достатності грошових коштів у підприємства. 3 урахуванням цього та виокремлення основних чотирьох підходів до детермінації платоспроможності, ми спробували надати власне, уточнене визначення.

Отже, на наш погляд, платоспроможність - це здатність суб' єкта господарювання своєчасно і в повному обсязі розрахуватися за своїми поточними борговими зобов' язаннями за рахунок власних наявних ресурсів із збереженням безперебійного здійснення основних процесів функціонування підприємства.

Дослідження сутності платоспроможності підприємства буде неповним без розуміння причинно-наслідкових зв'язків та закономірностей виникнення цього феномену, тобто без виявлення факторів, які вливають на платоспроможність того чи іншого суб'єкта.

Платоспроможність підприємства визначається складним комплексом факторів та їх системною взаємодією, що в повній мірі обумовлено ємністю самого явища. Класифікація факторів платоспроможності дає можливість моделювати процес іiї забезпечення, здійснювати комплексний пошук внутрішньогосподарських резервів 3 метою їі збереження або підвищення.

Пропонуємо власну класифікацію факторів платоспроможності, при цьому вважаємо за доцільне згрупувати всю різноманітність факторів впливу за наступними ознаками, таблиця 1.

Таблиця 1

Класифікація факторів платоспроможності підприємства*

\begin{tabular}{|l|c|c|}
\hline Класифікаційні ознаки & Види факторів & Характеристика \\
\hline \multicolumn{1}{|c|}{01} & 02 & 03 \\
\hline \multirow{2}{*}{ Місце виникнення } & внутрішні & $\begin{array}{c}\text { залежать від рішень та діяльності працівників } \\
\text { підприємства і пов'язані з їх можливими помилками }\end{array}$ \\
\cline { 2 - 3 } & зовнішні & $\begin{array}{c}\text { обумовлені середовищем, у якому функціонує } \\
\text { підприємство }\end{array}$ \\
\hline \multirow{2}{*}{$\begin{array}{l}\text { Ступінь } \\
\text { впливу }\end{array}$} & $\begin{array}{c}\text { ступінь впливу цих факторів носить переважний } \\
\text { характер }\end{array}$ \\
\cline { 2 - 3 } & основні & вплив даних факторів є несуттєвим \\
\hline
\end{tabular}


продовження таблиці 1

\begin{tabular}{|c|c|c|}
\hline Класифікаційні ознаки & Види факторів & Характеристика \\
\hline 01 & 02 & 03 \\
\hline \multirow[t]{2}{*}{ Результати впливу } & позитивні & підвищують показники платоспроможності \\
\hline & негативні & знижують показники платоспроможності \\
\hline \multirow[t]{2}{*}{ Взаємообумовленість } & залежні & фактори пов'язані між собою і виникають одночасно \\
\hline & незалежні & виникнення цих факторів не пов’язано між собою \\
\hline \multirow[t]{2}{*}{ Імовірність впливу } & фактичні & $\begin{array}{l}\text { вже безпосередньо впливають на } \\
\text { платоспроможність }\end{array}$ \\
\hline & потенційні & лише можливо будуть впливати в майбутньому \\
\hline \multirow[t]{2}{*}{ Час дії } & постійні & 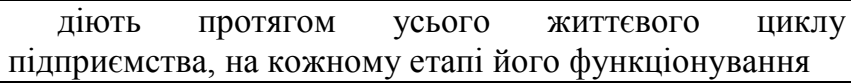 \\
\hline & тимчасові & $\begin{array}{c}\text { діють на платоспроможність підприємства } \\
\text { періодично або випадково (одноразові фактори) }\end{array}$ \\
\hline
\end{tabular}

* Розробка автора

Фактори можна поділити також і за іншими ознаками: за наслідками прояву (загальні, специфічні, індивідуальні); залежно від виду діяльності підприємства (операційної, фінансової та інвестиційної діяльності); за видами грошових потоків (такі, що впливають на розмір активів підприємства та ті, що впливають на його розмір пасивів). Внутрішні і зовнішні фактори можна розділити також на два великих класи - клас об'єктивних факторів (стадії життєвого циклу, рівень конкурентних переваг, стадії кругообігу капіталу у виробничому процесі) та клас суб'єктивних факторів (фінансова політика, облікова політика підприємства тощо).
Висновки та перспективи подальших досліджень. Запропоновану нами класифікацію факторів, які впливають на стан платоспроможності підприємства, ми не вважаємо вичерпною або повною. Однак, саме ці укрупнені групування, на нашу думку, $є$ найбільш важливими 3 огляду на подальший процес оцінювання цього явища та управління ним. Проводячи групування факторів впливу на платоспроможність підприємства, слід враховувати, що вони діють не ізольовано один від одного, а разом у великому комплексі. У той же час, залежно від стадії розвитку суб'єкта господарювання, вплив окремих факторів буде то знижуватися, то посилюватися.

\section{ПЕРЕЛІК ВИКОРИСТАНИХ ДЖЕРЕЛ}

1. Бердар М. М. Фінанси підприємств: [навчальний посібник] / М.М.Бердар. - К.: Центр учбової літератури, 2010. $-352 \mathrm{c}$.

2. Крейнина М. Н. Финансовый менеджмент: учебное пособие / Крейнина М. Н. - М.: Издательство "Дело и Сервис", 1998. - 304 с.

3. Іващенко В. І. Економічний аналіз господарської діяльності / В.І. Іващенко, М.А. Болюх. - К.: ЗАТ «НІЧЛАВА», 2001. - $204 \mathrm{c}$.

4. Зятковський І. В. Фінанси підприємств: Навчальний посібник / І.В. Зятковський. - 2-ге вид., перероб. та доп. - К.: Кондор, 2003. -364 c.

5. Макарчук I. М. Платоспроможність і ліквідність аграрних підприємств / І.М. Макарчук // Фінанси України. 2014. - №4. - C.120-126.

6. Мазаракі А. А. Економіка торговельного підприємства: підручник для вузів / А. А. Мазаракі, Н. М. Ушакова, Л. О. Лігоненко; під ред. проф. Н. М. Уша-кової. - К.: "Хрещатик", 1999. - 800 с.

7. Непочатенко О. О. Фінанси підприємств [текст]: підручник / О. О. Непочатенко, Н. Ю. Мельничук . - Київ : «Центр учбової літ», 2013 . - 504 с.

8. Ковалев В. В. Введение в финансовый менеджмент / Валерий Викторович Ковалев. - М.: Финансы и статистика, 1999. - 768 с. - (Научное издание).

9. Власова Н.О. Оцінка ліквідності та платоспроможності підприємств роздрібної торгівлі [Текст] : монографія / Н.О. Власова, Т.С. Пічугіна, П.В. Смірнова; Харк. держ. ун-т харчування та торгівлі - Харків, 2010. - 222 с.: іл. 19; табл. 41; бібліогр. 157 назв.

10. Экономическая стратегия фирмы / [под ред.. проф. Градова А.П.]. - [4-е изд., перераб.]. - СПб.: «Специальная Литература», 2003. - 959 с.

\section{REFERENCES}

1. Berdar, M.M. (2010). Finansy pidpryyemstv [Finances of the enterprises]. K.: Tsentr uchbovoyi literatury [in Ukrainian].

2. Kreynyna, M.N. (1998). Fynansovyy menedzhment [Financial mamagement]. M.: Yzdatel'stvo [in Russian]. 
3. Ivashchenko, V.I. (2001).Ekonomichnyy analiz hospodars'koyi diyal'nosti [Economic analysis of economic activity]. K.: ZAT «NICHLAVA» [in Ukrainian].

4. Zyatkovs'kyy I.V. (2003). Finansy pidpryyemstv [Finances of the enterprises]. K.: Kondor [in Ukrainian].

5. Makarchuk, I.M. (2014). Platospromozhnist' i likvidnist' ahrarnykh pidpryyemstv [Solvency and liquidity of agrarian enterprises]. Finansy Ukrayiny - Finances of Ukraine, 4, 120-126 [in Ukrainian].

6. Mazaraki, A.A. (1999). Ekonomika torhovel'noho pidpryyemstva [Economics of a trading enterprise]. K.: «Khreshchatyk» [in Ukrainian].

7. Nepochatenko, O.O. (2013). Finansy pidpryyemstv [Finances of the enterprises]. Kyiv: «Tsentr uchbovoyi lit» [in Ukrainian].

8. Kovalev, V.V. (1999). Vvedenye v fynansovyy menedzhment [Introduction to financial management]. M.: Fynansy y statystyka [in Russian].

9. Vlasova, N.O. (2010). Otsinka likvidnosti ta platospromozhnosti pidpryyemstv rozdribnoyi torhivli [Assessment of liquidity and solvency of retail enterprises]. Kharkiv [in Ukrainian].

10. Ekonomycheskaya stratehyya fyrmy [Economic strategy of a firm]. (2003). SPb.: «Spetsyal'naya Lyteratura» [in Russian].

Одержано 28.01.2019 